\title{
Development of Interactive Learning Model Based on E-Learning on Instructional Design
}

\author{
Sahat Siagian ${ }^{1}$, Pardomuan Naulli Josip Mario Sinambela ${ }^{2}$ and Yasaratodo $\mathrm{Wau}^{3}$ \\ \{sahatsgn61@gmail.com ${ }^{1}$, pardomuanjmsinambela@gmail.com ${ }^{2}$, yasaratodo@gmail.com ${ }^{3}$ \} \\ Education Technology Program, Postgraduate Studies Faculty, Universitas Negeri Medan. Indonesia ${ }^{1}$ \\ Mathematics Program, Faculty of Mathematic and Natural Sciences,Universitas Negeri Medan. \\ Indonesia $^{2}$ \\ Out of School Education Program, Faculty of Education Studies, Universitas Negeri Medan. \\ Indonesia $^{3}$
}

\begin{abstract}
This study aims to develop an interactive e-learning based learning model assisted by the Edmodo program in the instructional Design Course, this research is expected to produce (1) produce e-learning based interactive learning model that are feasible to use, easy to learn and can be used for individual learning and learning material that refers to the competencies that have been set, (2) to find out the result of the implementation of e-learning based. Interactive Learning Model in instructional design cources and the right strategies used in instructional design learning, (3) to determine the effectiveness of e-learning interactive Learning Models learning develop in instructional design cources as well as to find out effective and efficient interactive learning models. This research was conducted in the State University of Medan Post Graduate, Education Technology Study Program in 2016 until 2018. The target populationwas all student who were receiving Instructional Desgncources. The Sampling technique used in Cluster Random Sampling. To achieve this research, the overall research uses research and development methods by following the steps of the preliminary survey, media planning, media testing, media testing, media validation and socialization. This research was carried out in there stages 2017 is a research in the second year at the Validation stage. Validation carried out includes validation of media experts and design and material experts. In validation to validation by experts, individual valudation was also carried out on 3 students, then group validation of 5 students after improving individual validation result. After that the validation is done on the actual class.
\end{abstract}

Keywords: Model, Development, e-Learning

\section{Introduction}

The success of improving the quality of human resources through education is related to various aspects, one of which is the ability of lecturers to design a learning process. In this regard, Rooidjakkers (1993) states that teaching is an attempt to transmit knowledge to others [1]. Furthermore, Gagné, Briggs and Wager (1992) say that learning is an activity that can make learners learn and easily know what is delivered [2]. The achievment of this can not be separated from the use of learning media which is a tool to deliver messages. This is in accordance with the opinion of Jaemu Lee and Yong-Jae Lee who stated that: "The successful design of e-learning relies on careful consideration of the underlying pedagogy of how 
learning takes place online and e-Learning will yield new levels of institutional and instructional productivity [3].

The development of science and technology has led to changes in learning materials. There are two types of learning material, namely written teaching materials and teaching materials as learning media, or called printed teaching materials and non-printed teaching materials. Non-printed teaching materials are teaching materials developed to enrich students' understanding of the subject matter learned, in addition to filling in the shortcomings that arise due to reading culture problems as well as time constraints and to answer the diversity of student learning styles. The development of non-printed teaching materials must be able to make the most of its media capabilities. In other words, the selection of material in accordance with the specified media is an important first step, using a language that is simple, communicative and clear, capable of involving students' thinking processes, and allowing students to achieve a level of mastery independently.

Education that gets a touch of information technology media has sparked the birth of the idea of e-learning or electronic learning. There are various types of e-learning such as Moodle, Blackboard, Sakai, Dokeas and edmodo assisted e-learning which are currently the most widely used. E-learning is learning that uses electronic circuits or internet networks to convey the content of learning, interaction or guidance (Rusman, 2009: 49). In addition, e-learning as a form of distance education is done through internet media. E-learning is also an indirect (asyinchronous) learning activity through computer electronic devices to obtain learning material that suits their needs.

Educational Technology Study Program (ET) is one of the study programs in the Faculty of Postgraduate Studies at the State University of Medan. One of the Educational Technology areas is the utilization area, so the use of information technology in learning activities is needed in improving the quality of learning and naturally the learning outcomes of students will increase. Pratama (2014: 45) said, that some of the problems that occur in learning in the world of education are (1) most of the learning concepts that are carried out are abstract, (2) limited time available to teach material to be delivered and (3) lack of participation learners in the learning process. Pratama (2014: 45) also found that these problems can be overcome by using concrete models of teaching materials in the form of images, animations or videos delivered by teaching staff and applying learning approaches that involve students, which can be done by utilizing the internet as a communication tool to maximize the participation of students so that the limitations of time constraints can be overcome, and provide teaching materials that can be learned individually by students outside the classroom.

This form of learning innovation is by integrating the instructional design learning process with Communication Information Technology which is better known as e-learning based interactive learning. One of the most interactive e-learning models based on instructional design learning is Edmodo-assisted interactive learning model. Edmodo is a site used by teachers / lecturers, students and parents to facilitate the online learning process. The main goal of making EDMODO as a social media tool that helps connect teachers and students in each school also ensures they are connected throughout the world. Edmodo spurs a safer and easier class to connect with one another, offering a real time-based platform to exchange ideas, content, and access homework, values, and important information from school. This interactive learning model helps to plan, analyze, implement, manage learning and provide access to learners of the material whenever and wherever students are. 


\section{Methodology}

\subsection{Development Model}

The research method used is the development method. The development model used was a modified version Borg and Gall (1983) development model [7]. The steps of the development stage are as follows: 1) Research and information collecting (Planning and Initial Information Collection). In this case, literature studiesrelated to the problems are conducted, 2) Planning. At this stage the activities are related to the formulation of skills and expertise related to the problem, 3) Developing a preliminary version of product. At this stage, an initial form of elearning model will be developed that will be produced in the development of learning models, 4) Preliminary field testing. This stage is a stage of testing on a limited scale based on observation or questionnaire, 5) Main product revision (Revision of Learning Products). At this stage, it will be reviewed and improvements to the initial learning products produced based on the results of the initial trial will be made, 6) Operational product revision. At this stage there will be improvements based on the results of a wider trial, 7) Final product revision. At this stage improvements will be made to the developed learning model, 8) Dissemination. At this stage implementation activities will be carried out.

The syntax of the learning model offered is as follows

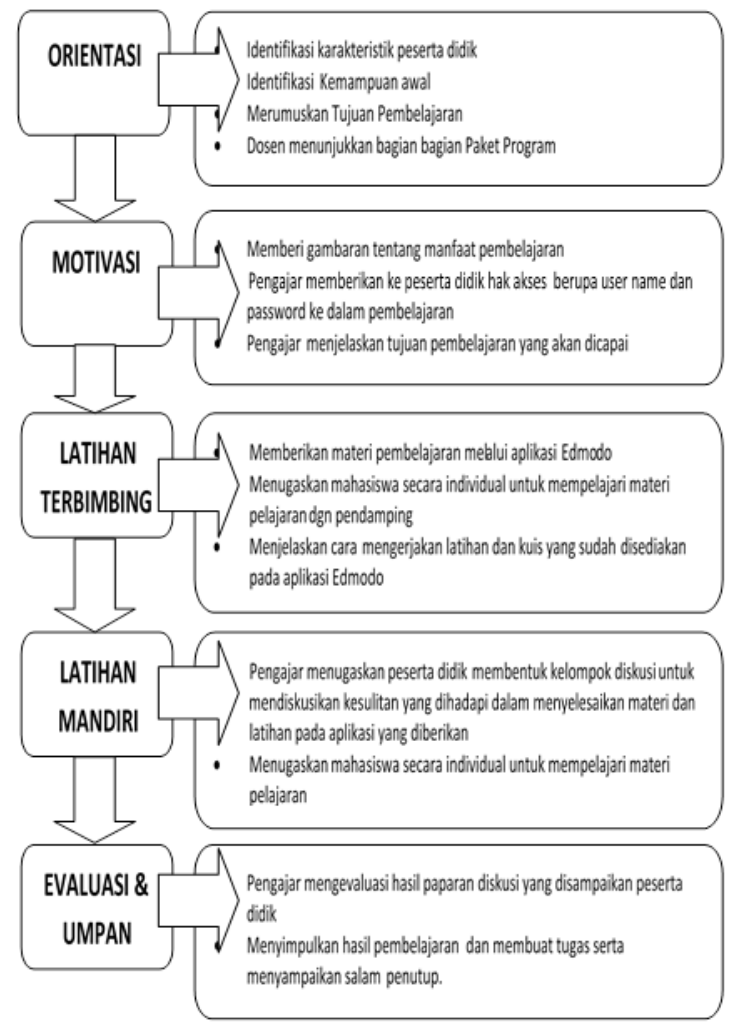

Figure1: E-Learning Syntax 


\subsection{Research Procedure}

This research will actively involve students, both in the preliminary studies, product development, development of teaching materials, product testing and final product design. Systematically, the research that will be conducted is as follows:

This research was carried out in three stages. Each stage is the implementation of the year. At this stage the research was carried out in the first stage. The first phase of this activity is toanalyze the elearning media that is most appropriate to be used in instructional design learning, through surveys in preliminary studies, including identification of learning needs, identification of student characteristics, identification of students' initial abilities, as well as the competency standards of courses which include analysis of learning. Moreover, identification of the characteristics and initial behavior of students, determination of basic competencies and indicators are also conducted. The learning outcomes test that will be made in e-learning is a benchmark reference test. The next activity is to develop learning strategies, develop learning materials. In addition, in this learning there is also a quiz that must be completed by students, therefore it is necessary to compile questionsat the end of each specified material and provide feedback. Then, proceed with the preparation and design of the software including: making a script, making a storyboard, and making a flowchart view.

The second stage is the second year. The activities carried out at this stage are collecting materials, including: making and collecting images and animations, recording and collecting audio, developing and making interactive e-learning learning media. The next activity is a study of the media, competencies, and learning materials that have been found in the first stage. Learning media, learning materials, competencies will be tested on small and large scale as well as input for the initial stage revision. Thus, in the second initial phase there will be limited trials, large-scale trials, revisions, and finished results. In the second phase of the study, a trial method was used through the procedure (a) expert review, (b) oneon-one trials, (c) small group trials, and (d) large group trials (real class) for learning media which is operational.

The third stage is the third year. Activities carried out at this stage are preparing guidelines (guidelines) for the implementation of the use of interactive e-learning learning media, evaluation, dissemination and development that can be carried out in the form of experiments to see the effectiveness and efficiency of interactive learning media products developed. 


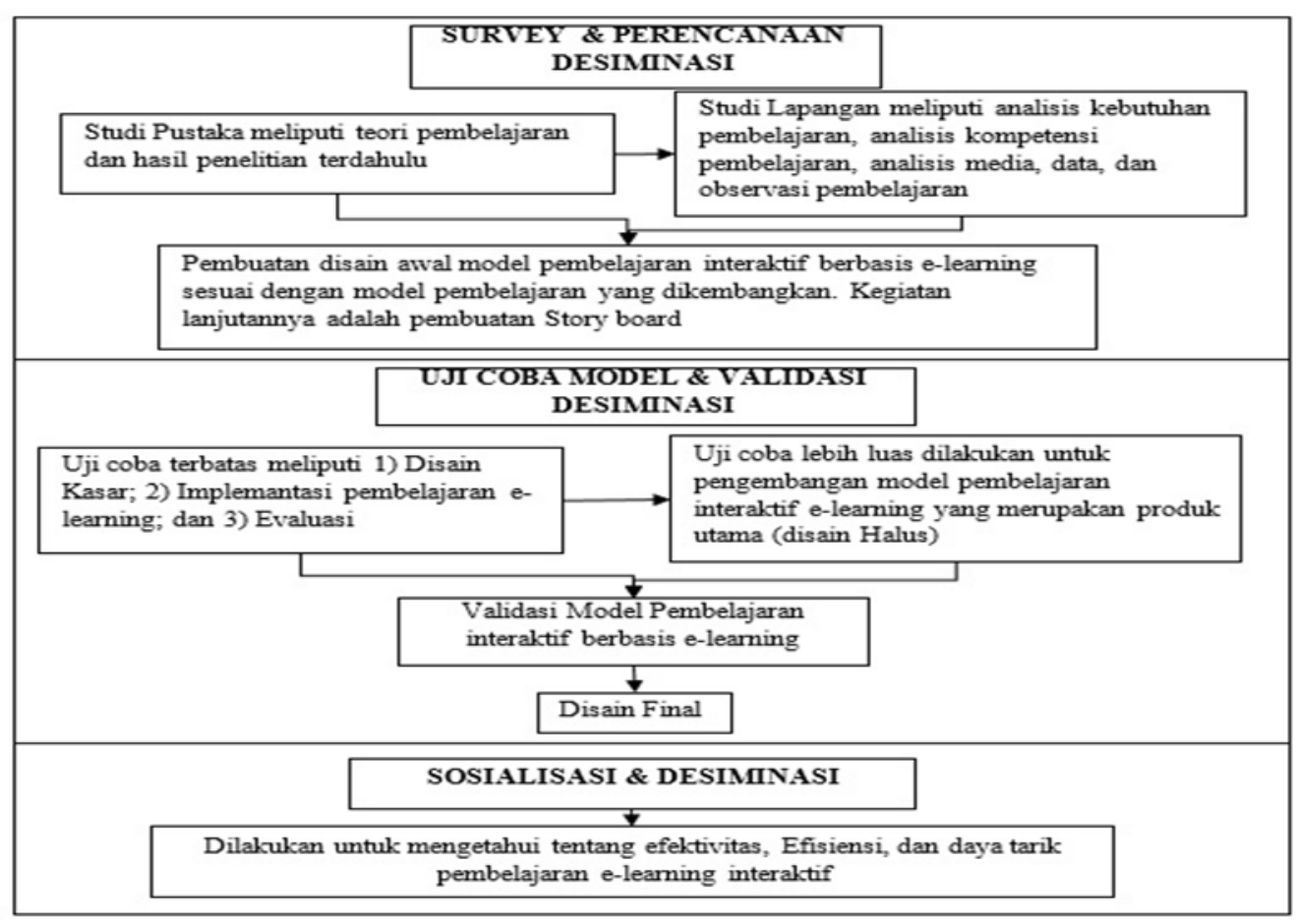

Figure 2: Research Procedure Syntax

\subsection{Data Collection and Analysis}

For measurement of the effectiveness and practicality of e-learning-based interactive learning models in this study, the e-learning used is Edmodo. Thus, several research instruments were developed and compiled that will be used in the study. Before the Instrument was used, the trial included: includes: expert trials, individual trials, small groups and actual large groups or groups.

\section{Results}

Based on the results of product development, it was found that Edmodo-assisted e-learning for instructional design courses contained several important menus including evaluation, presentation, discussion, lecture assignments, teaching materials, instructional media, important links, learning tools, and plagiarism check.

Main Menu contains a description of the instructional design courses and the lecturers involved in this course. The Evaluation Menu contains items related to the formative. Besides that, it also presents the evaluation material that will be tested. Presentation menu contains the material thatwill be presented such as instructional needs analysis, instructional analysis, development of benchmark reference tests, learning strategies, development of teaching materials. The discussion menu contains important things that need to be discussed related to the basic competencies that exist in instructional design courses. Lecture Task Menu is a 
collection of tasks that students must complete according to the time displayed on this menu. Delay in collecting assignments online indicates that the student is unable to send it back, except with the permission of the subject lecturer. Menu of Teaching Materials is a collection of teaching materials that will be used in Edmodo-assisted e-learning. Students can download instructional materials presented by course lecturers with the permission of the lecturer. Learning Media Menu presented several materials related to learning media. This material can be in the form of powerpoint, word document, excel sheet, images which include extension jpg, bmp, etc., as well as videos with wmv and other extensions. Link menu contains several links related to instructional design learning materials. This link is a web address that can be used to add information to students regarding additional material needed. Learning Device Menu contains learning tools in instructional design courses. The devices in question include lecture contracts, semester learning plans, quizzes, and others. Check Plagiarism menu can check the tasks collected by students for plagiarism. This is needed especially in the assessment. The lecturer must be able to give a good assessment related to the creativity of the student's work. The check plagiarism menun is presented as follows.

\subsection{Validation Result Data}

\subsubsection{Expert Validation Results Data on Material}

Validation of learning devices based on material Expert is to obtain information related to the compatibility between the material presented in Edmodo-assisted e-learning and the basic competencies found in instructional design course. The material expert in this case involves competent people in their fields. The basic competencies and indicators that will be studied in this course are some basic competencies and several indicators derived from basic competencies.

Evaluation of material experts on the development of EDMODO-assisted e-learning based interactive learning tools for instructional design courses was conducted by Education Technology lecturers at the State University of Medan. Assessment is done to get information about the quality of learning on instructional design course. The validator involved in material validation consists of two experts. Expert validation scores of edmodo-assisted e-learning based interactive learning materials can be seen in table 1.

Table 1. Expert Validation Score on Learning Materials

\begin{tabular}{lll}
\hline \multicolumn{1}{c}{ Assessment } & \multicolumn{1}{c}{ Average } & Criteria \\
\multicolumn{1}{c}{ Indicator } & & \\
\hline Content Aspect & $\mathbf{4}$ & Good \\
Presentation Aspect & $\mathbf{3 . 8 6}$ & Good \\
Language Aspect & $\mathbf{4 . 8}$ & Very good \\
Overall average & 4.22 & Very good \\
\hline
\end{tabular}

There are three important things that are validated in the material, namely aspects of content appropriateness, aspects of presentation appropriateness, and linguistic appropriateness aspects. Based on the table, it is obtained that for the aspect of content 
appropriateness, the average score is 4 and is in the good category. Furthermore, for the aspect of presentation appropriateness, the average score was 3.86 and in the good category, while for the aspect of linguistic appropriateness, the average score was 4.8 and in the very good category. Based on the table, the overall average is 4.22 or in the very good category. Based on this, it was found that learning material could be used.

\subsubsection{Expert Validation Results Data on Learning Media}

Validation of learning media was carried out to obtain information about product evaluation in several aspects including aspects of usage, navigation system, graphic design, content, accessability, access speed, and function. Validator that validates learning media consists of three experts. Expert validation scores on edmodo-assisted e-learning-based interactive learning media can be seen in the table 2 .

Table 2. Expert Validation Score on e-learning Media

\begin{tabular}{lll}
\hline $\begin{array}{l}\text { Assessment } \\
\text { Indicator }\end{array}$ & Average & Criteria \\
\hline Utility & $\mathbf{4 , 3 3}$ & Very good \\
Navigation System & $\mathbf{4 , 6 7}$ & Very good \\
Graphic Design & $\mathbf{4 , 4 8}$ & Very good \\
Content & 4,52 & Very good \\
Accesability & 4,00 & Good \\
Speed of Acces & 3,92 & Good \\
Function & 3,83 & Good \\
Overall average & 4.25 & Very good \\
\hline
\end{tabular}

Some indicators that are validated by experts related to e-learning media include the use of an average score of 4.33 with very good categories, the navigation system obtained an average score of 4.67 with a very good category, graphic design obtained average average score of 4.48 with a very good category, content / content obtained an average score of 4.52 with a very good category, access ability obtained an average score of 4.00 with good category, access speed obtained an average score amounting to 3.92 with good category, and the function obtained an average score of 3.83 with good category. The average overall score of the indicator is 4.25 and is in a very good category. Evaluation results from media experts were analyzed by developers and discussed again with media experts as a basis for revision to improve instructional design learning design. Overall, the assessment, input and suggestions from material experts and media experts serve as the basis for making decisions to carry out the revision of the role of material experts. Yet, media experts did not stop at this stage; the discussion of the revised results continued until the e-learning-based interactive learning tools were finished and ready to be disseminated.

\subsubsection{Individual Trial Test Data Result (Restricted)}

Individual trials were conducted at the Education Technology study program at the State University of Medan. Individual trials were conducted on three random students who had high achievement, moderate achievement, and low achievement each. The purpose of this 
individual trial is to identify the shortcomings of edmodo-assisted e-learning-based interactive learning model. Data on individual trial results can be seen in the table 3:

Table 3. Indivual Trial Test Data

\begin{tabular}{lll}
\hline Assessment indicators & Average & Criteria \\
\hline Display Aspect & $\mathbf{3 , 8 3}$ & Good \\
Material Aspect & $\mathbf{4 , 0 0}$ & Good \\
Information Aspect & $\mathbf{4 , 1 3}$ & Very good \\
Overall average & 3.99 & Good \\
\hline
\end{tabular}

There are three aspects tested in individual trials including aspects of appearance. In this aspect of view there are eight indicators that are used as a reference. Based on the results of individual trials, the average score was 3.83 and in the good category. The next aspect is the material aspect. In this aspect there are nine indicators that will be assessed. This material aspect obtained an average score of 4 and was in the good category. The last aspect is the aspect of information. In this aspect there are five indicators that are assessed. In this aspect an average score of 4.13 was obtained and in the Very good category. Based on the table, the overall average score is 3.99 and is in the good category.

\subsubsection{Small Group Data Test Result}

Small group trials were carried out in the same class involving five students consisting of 2 high-achieving students, 2 middle-achieving students and 1 low-achieving student. This small group trial data is intended to find out some of the weaknesses or obstacles faced when the elearning based interactive learning model with Edmodo is done in a wider trial. This small group trial was used as an initial experience before the e-learning model was tested in the field. The small group test results data can be seen in the table 4 .

Table 4. Small Group Test Results Data

\begin{tabular}{lll}
\hline $\begin{array}{c}\text { Assessment } \\
\text { Indicator }\end{array}$ & Average & Criteria \\
\hline Display Aspect & $\mathbf{3 , 9 1}$ & Good \\
Material Aspect & $\mathbf{4 , 0 7}$ & Very good \\
Information Aspect & $\mathbf{4 , 0 4}$ & Very good \\
Overall average & 4.01 & Very good \\
\hline
\end{tabular}

There are three aspects that are tested in small group trials including aspects of the display which involve eight indicators as a reference for assessment. Based on the results of the small group trial, the average score was 3.91 and in the good category. The next aspect is the material aspect. In this aspect there are nine indicators that are used as a reference for assessment. In this material aspect an average score of 4.07 is obtained and is in the Vary good category. The last aspect is the aspect of information. In this aspect there are five indicators that are assessed. In this aspect, the average score is 4.04 and is in the Vary good category. Based on the table, the overall average score was 4.01 and was in the Very good category. 


\subsubsection{Large Group Trials (Field Test) Data Results}

Large group trials or field trials were carried out by first correcting the deficiencies of existing deficiencies found in initial product trials, individuals and small group tests. Large group trials were carried out in two classes, namely class A and class B in the study program of Education Technology with a total of 23 students. Large group trials were conducted at the State University of MedanPostgraduate Program. Each student uses a computer that is connected to the internet in the learning process. From the results of the large group trial, the data obtained can be seen in the table 5 .

Table 5. Large Group Test Results Data

\begin{tabular}{lll}
\hline $\begin{array}{c}\text { Assessment } \\
\text { Indicator }\end{array}$ & Average & Criteria \\
\hline Display Aspect & $\mathbf{4 , 2 4}$ & Very good \\
Material Aspect & $\mathbf{4 , 4 1}$ & Very good \\
Information Aspect & $\mathbf{4 , 4 3}$ & Very good \\
Overall average & 4.36 & Very good \\
\hline
\end{tabular}

The same is true for small group trials. In the large group trial there were three aspects tested including aspects of the display which involved eight indicators as a reference for assessment. Based on the results of the trial of large groups on display aspect, an average score of 4.24 is obtained and is in a very good category. The next aspect is the material aspect. In this aspect there are nine indicators that are used as a reference for assessment. In this material aspect, the average score was 4.41 and in the very good category. The last aspect is the aspect of information. In this aspect there are five indicators that are assessed. In this aspect an average score of 4.43 is obtained and is in a very good category. Based on the table, the overall average score was 4.36 and in the very good category.

\subsection{Data Analysis}

\section{a. Validation Data Analysis for Material Experts}

Validation carried out by material experts related toEdmodo-assisted e-learning-based interactive learning covers three aspects, namely aspects of content appropriateness, aspects of presentation appropriateness, and linguistic appropriateness aspects. Based on the data obtained, the average presentation appropriatenss aspect score has the lowest score compared to the other aspects of 3.86 and is in the good category. The content appropriateness aspect has an average score of 4 and is in the good category and linguistic appropriateness aspecthas an average score of 4.8 and is in the very good category. On average, the overall aspects were at 4.27 and in the very good category. The results of the assessment of the material indicate that the errors in the material are very small errors and can be ignored such as typing errors which can be improved by revising. 


\section{b. Media Expert Validation Data Analysis}

Assessment conducted by media experts shows that overall it has been very good, which is indicated by the average overall score obtained at 4.25 . The aspect that has the lowest average score is the function aspect of 3.83, even though the average score is still in the good category. There are seven aspects that are assessed in this media validation, namely 1) aspects of utility with an average score of 4.33 and in the very good category, 2) navigation aspect with an average score of 4.33 and in the very good category , 3) aspect of graphic design with an average score of 4.48 and in the very good category, 4) the aspect of content with an average score of 4.52 and in the very good category, 5) aspect of accessability with an average score of 4 and in good category, 6) access speed with an average score of 3.92 with good category, and 7) function aspect with an average score of 3.83 and in good category. Based on the experts' opinion, it was stated that edmodo-assisted e-learning-based interactive learning was feasible to be tested and revised according to the advice given. The experts state that interactive learning based on edmodo-assisted e-learning is acceptable and much needed.

\section{c. Analysis of Individual Trial Results Data}

Based on the results of the trial data conducted on three students, the average overall score was 3.99 and in the good category. There are three aspects as the indicators in the assessment related to the individual ciba test. The aspect that has the highest score average is the aspect of information that is equal to 4.13. The highest score in this aspect of information is indicated by the indicator for giving new information, with an average of 4.67. This shows that edmodoassisted e-learning based interactive learning is very helpful for students to obtain information according to their learning needs. The aspect that has the lowest average score is the aspect of display with an average score of 3.83. This shows the need for improvement on input that has been made in this trial. The lowest indicator in this aspect is an indicator of navigation with a score of 3.00. Although this aspect has the lowest score, this aspect is in the good category. Another aspect is the material aspect. In this aspect, the average score was 4.00 and in the good category. Indicators that have the highest score are indicators of material suitability and ease of understanding sentences in the text which is indicated by a score of 4.67. This shows that all the material presented is in accordance with the needs of the subject and the needs of students. The following are the aspects of each student based on individual trials.

Table 6. Individual Test Results Data Table based on each student

\begin{tabular}{llll}
\hline \multicolumn{1}{c}{$\begin{array}{c}\text { Assessment } \\
\text { Indicator }\end{array}$} & Student $\mathbf{1}$ & Student 2 & Student 3 \\
\hline Display Aspect & 3,63 & 3,88 & 4,00 \\
Material Aspect & $\mathbf{3 , 8 9}$ & $\mathbf{4 , 1 1}$ & $\mathbf{4 , 0 0}$ \\
Information Aspect & $\mathbf{4 , 2 0}$ & $\mathbf{4 , 0 0}$ & $\mathbf{4 , 2 0}$ \\
Average & 3,87 & 3,99 & 4,05 \\
Criteria & Good & good & Very good \\
\hline
\end{tabular}

Based on the data obtained it can be seen that each student gives an average score of 3.87, 3.99, and 4.05 which is in the category of good, good, and very good. This shows that edmodo-assisted e-learningbased interactive learning can be used for the next phase of testing. 


\section{d. Analysis of Small Group Test Results Data}

Based on the data from the trials conducted on five students, the average overall score was 4.01 and in the good category. In this case the average score obtained has increased compared to individual trials, this is because there have been improvements made. There are three aspects as indicators in the assessment related to small group trials. The aspect that has the highest average score is the aspect of the material that is equal to 4.07. The highest score in this aspect of information is indicated by the indicator for giving new information, with an average of 4.60. This shows that edmodo-assisted e-learning based interactive learning is very helpful for students to obtain information according to their learning needs. The aspect that has the lowest average score is the aspect of display with an average score of 3.91. This shows that there is still a need to improve the input that has been made in this trial. The lowest indicator in this aspect is a navigation indicator with a score of 3.40. This indicator has increased from the previous one which only got a score of 3.00. Although this aspect has the lowest score, this aspect is in the good category. Another aspect is the material aspect. In this aspect, the average score is 4.07 and is in the very good category. Indicators that have the highest score are indicators of material suitability, accuracy of the order of presentation, and ease of understanding the ease of understanding the subject matter presented in accordance with the needs of the course and the needs of students. The following are the aspects of each student based on individual testing.

Table 7. Small Group Test Results Data Based on Each Student

\begin{tabular}{cccccc}
\hline $\begin{array}{c}\text { Assessment } \\
\text { Indicator }\end{array}$ & $\mathbf{S 1}$ & $\mathbf{S 2}$ & $\mathbf{S 3}$ & $\mathbf{S 4}$ & $\mathbf{S 5}$ \\
\hline Display Aspect & $\mathbf{4 , 0 0}$ & $\mathbf{4 , 0 0}$ & $\mathbf{4 , 1 3}$ & $\mathbf{4 , 0 0}$ & $\mathbf{3 , 3 8}$ \\
Material Aspect & $\mathbf{4 , 1 1}$ & $\mathbf{4 , 2 2}$ & $\mathbf{3 , 7 8}$ & $\mathbf{4 , 0 0}$ & $\mathbf{4 , 2 2}$ \\
Information Aspect & $\mathbf{4 , 4 0}$ & $\mathbf{4 , 0 0}$ & $\mathbf{4 , 2 0}$ & $\mathbf{3 , 6 0}$ & $\mathbf{4 , 0 0}$ \\
Average & 4,14 & 4,09 & 4,00 & 3,91 & 3,86 \\
Criteria & Very good & Very Good & Good & Good & Good \\
\hline S = Student & & & & &
\end{tabular}

Based on the data obtained it can be seen that each student gives an average score of 4.14 , $4.09,4.00,3.91$ and 3.86 which is in the category of very good, very good, good, good and good. This shows that edmodo-assisted e-learning-based interactive learning can be used for trials in large groups.

\section{e. Analysis of Large Group Trial Results Data}

Based on the results of the trial data conducted in two classes with 30 people on average, the overall score was 4.36 and in very good category. In this case the average score obtained has increased compared to the previous small group trials, this is because there have been improvements made. There are three aspects that become indicators in the assessment related to small group trials. The aspect that has the highest average score is the aspect of the material that is equal to 4.41. The highest score in this aspect of information is shown by the ease of understanding of the text indicator with an average of 4.87. This shows that interactive learning based on edmodo-assisted e-learning is very easy to understand in terms of language and is very helpful for students to obtain information according to their learning needs. The 
aspect that has the lowest average score is the aspect of view with an average score of 4.24. However, this aspect is in a very good category. The lowest indicator in this aspect is an indicator of video quality with a score of 4.03. This indicator has increased from the previous one wich only got a score of 3.67. Although this aspect has the lowest score, this aspect is already in a very good category. Another aspect is the aspect of information. In this aspect, the average score was 4.43 and in the very good category. The indicator that has the highest score is a new information giving indicator with an average score of 4.83 . This shows that all information presented is in accordance with the needs of the course and the needs of students.

\section{Conclution}

From the results of the research and development stages that have been carried out, it can be concluded that: almost all students responded positively about Edmodo-assisted e-learningbased Interactive Learning Tool, in the context that is beneficial, interesting, and can increase student learning motivation, which is done in data collection for the needs analysis. Judging from the general aspects, software engineering, visual communication, the substance of the material and learning, the Edmodo-assisted e-learning-based Interactive Learning tool proved to have shown results in good categories. From the results of validation and product testing, with several criteria that have been established in the planning of research and development methods. The use of Edmodo-assisted interactive learning based on e-learning provides convenience to lecturers and students in absorbing lecture material

\section{References}

[1] Gagné, R.M., Briggs, L.J ., Wager, W.W.: Principles of Instruction Design. Saunders College Publishing, New York (1992)

[2] Jaemu Lee., Yong-Jae Lee.: Development and Application of E-Learning Content for Advertising Education. International Journal of Advanced Science and Technology. pp 1-12. (2012)

[3] Mohamed, J.M., Oso Willis.,: Strategic Model Of Implementing E-Learning. International Journal Of Scientific \& Technology Research. pp. 235-238 (2014)

[4] FirouzAnaraki.: Developing an Effective and Efficient eLearning Platform. International Journal of The Computer, the Internet and Management. pp. 57-63 (2004)

[5] Borg, W.,V Gall, M.D.: Educational Research. An Introduction (4nded). Longman, New York \& London (1983)

[6] AECT.: Definisi Teknologi Pendidikan. (satuan tugas definisi \& terminologi AECT). Rajawali, Jakarta (1997)

[7] Degeng, I. N.: Paradigma Baru Pendidikan Memasuki Era Desentralisasi dan Demokratisasi. Makalah Seminar Regional: 19 April. Universitas PGRI, Surabaya (2000)

[8] Dick, W.,Carey, L. The Systematic Design of Instruction. Scott Foresman and Company, United States of America (2005)

[9] Heinich, Robert, et. Al.: Instructional Media and Technologies for Learning (5thed). A Simon \& Schuster Company Engelewood Cliffs, New Jersey (1996)

[10] Kemp.: Design Effective Instruction. Macmillan College Publishing Company, New York (1994)

[11] Merrill,M.D.: Teaching Concepts: An Instructional Design Guide. Educational Technology Publications, New Jersey (1997)

[12] Sadiman, A.,dkk.: Media Pendidikan, Pengertian, Pengembangan dan Pemanfaatannya . Pustekkom Dikbud, Jakarta (2003) 
[13] Seells dan, Richey.: Instructional Technology (Mahasiswa S2 IKIP Malang Terjemahan). IKIP Malang (1996)

[14] Smaldino, E. S., dkk... Instrucional Technology and Media For Learning. Upper Saddle River, New Jersey (2008)

[15] Suparman, A.: Desaininstruksional. Pusat antar Universitas untuk Peningkatan dan Pengembangan Aktivitas Instruksional. Direktorat Pendidikan Tinggi, Departemen Pnedidikan Tinggi, Jakarta (2001) 